\author{
STATE OF ILLINOIS \\ WILLIAM G. STRATTON, Governor
}



\title{
Frequency of Point and Areal Mean Rainfall Rates
}

by

F. A. HUFF AND J. C. NEILL

\author{
Issued by \\ DEPARTMENT OF REGISTRATION AND EDUCATION \\ VERA M. BINKS, Director \\ STATE WATER SURVEY DIVISION \\ WILLIAM C. ACKERMANN, Chief \\ URBANA, ILLINOIS \\ (53095-3-57) \\ 4 \\ (Printed by authority of the State of Illinois)
}




\title{
Frequency of Point and Areal Mean Rainfall Rates
}

\author{
F. A. HUFF AND J. C. NEILL
}

\begin{abstract}
Use of special recording raingages enabled recording of one-minute rainfall amounts from a 50-gage network on a 100-sq mi area in central Illinois during the 1952-53 thunderstorm seasons. One-minute amounts from 19 storms during this period have been used to study the frequency of rainfall rates in shower-type storms under warm season conditions, on both a point-rainfall and areal-mean-rainfall basis. Within the 100-sq mi area, smaller areas of 10, 25, and $50 \mathrm{sq}$ mi were used to obtain an indication of the effect of changing area on the distribution of areal mean rates. The expected tendency for the mean rate to decrease with increasing area was found. For example, the median rate for all 19 storms combined ranged from 1.45 inches per hour for point rainfall to 0.96 inch per hour for the 25 -sq mi area to 0.66 inch per hour for the 100-sq mi basin.

The degree to which averaging suppresses details of high rates, as well as the general effects of the averaging process on the distribution curve, was also studied by comparing the distribution of point rates when the rates were based on 1-, 5-, 10-, 15- and 30-minute averages. Results showed the maximum observed rate ranging from 13.80 inches per hour for one-minute to 2.45 inches per hour when based on a 30-minute average. Similarly, when all 19 storms were combined, the median rate ranged from 1.45 inches per hour for one-minute averages to 0.56 inch per hour for 30-minute averages.
\end{abstract}

Introduction-During 1952-53, one-minute rainfall totals for a number of storms were tabulated in conjunction with a project concerned with the investigation of the utility of radar for quantitative rainfall measurements [Neill, 1953]. Use of special recording raingages with 12.6-inch diameter orifices and six-hour charts enabled recording of one-minute amounts from the raingages. Information on the occurrence of rainfall rates within storms should be of interest to hydrologists, especially to those interested in sedimentation and in the design of reservoirs and small drainage systems such as urban storm sewers. Such information is also valuable in evaluating radar for quantitative precipitation measurements and other meteorological uses, since precipitation attenuation is proportional to the rainfall rates within a storm, and attenuation presents an outstanding problem in applying radar to the measurement of rainfall intensity [Huff and others, 1956]. Consequently, an analysis was made of the frequency of occurrence of point and areal mean rainfall rates. The available data were restricted to shower-type rainfall occuring during the thunderstorm season from late spring to early fall.

Data used in analysis-One-minute rainfall amounts from 19 storms during 1952-53, tabulated in conjunction with the radar-rainfall project mentioned previously, were used in the study. The one-minute amounts were obtained from 50 recording gages located on a 100 -sq mi area encompassing the Goose Creek Watershed in east central Illinois. (Operation of the network and data reduction were partly sponsored by the Signal Corps Engineering Laboratories, Belmar, New Jersey under contract DA-36-039 SC-42446.) The distribution of gages on the network was approximately uniform, the uniformity being limited only by existing road systems and suitable exposures. The network terrain is relatively flat with no distinct topographic features to influence storm behavior.

Careful attention was given to synchronizing the gages so that one-minute rainfall patterns and areal means could be reliably represented. All clocks were checked for accurate timing before installation each spring. Before proceeding to the network to change charts, observer's watches were synchronized with a master clock, which was checked daily with time signals from radio station WWV, the National Bureau of Standards station at Washington, D. C. When installing and removing charts from the drum, the observer made a vertical time check mark with the pen on the chart and entered the exact 'on' or 'off' time from his watch. Charts were changed after each storm and twice a week during periods of no rain to keep any clock-timing errors small. When a raingage record indicated the gage clock had gained or lost a small amount of time, the error was prorated over the period of record. As a further check, after isohyetal maps were plotted for each minute of a storm, gage charts were re-examined if doubtful values appeared at any stations on a one-minute map.

Frequency of point-rainfall rates-The frequency of occurrence of point-rainfall rates in each storm was calculated first, using the data from all 50 


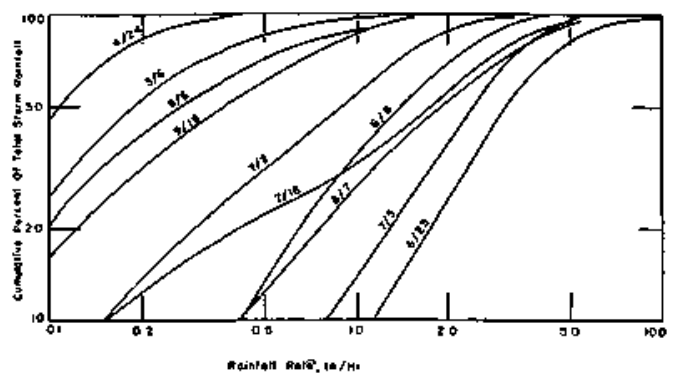

FIG. 1 - Distribution of point rainfall rates in individual storms

TABLE 1 - Frequency of rainfall rates calculated from various periods (in minutes)

\begin{tabular}{r|c|c|c|c|c}
\hline \multirow{2}{*}{$\begin{array}{c}\text { Cumu- } \\
\text { ative } \\
\text { per } \\
\text { cent }\end{array}$} & \multicolumn{5}{|c}{ Rainfall rate (in/hr) equaled or exceeded for } \\
\cline { 2 - 6 } & 1 & 5 & 10 & 15 & 30 \\
\hline Max. & 13.80 & 7.50 & 5.72 & 4.20 & 2.45 \\
5 & 5.35 & 4.10 & 3.25 & 2.64 & 1.62 \\
10 & 4.20 & 3.35 & 2.80 & 2.34 & 1.41 \\
20 & 3.25 & 2.58 & 2.13 & 1.93 & 1.15 \\
30 & 2.45 & 2.02 & 1.75 & 1.42 & 0.88 \\
40 & 1.90 & 1.52 & 1.34 & 1.07 & 0.69 \\
50 & 1.45 & 1.16 & 0.97 & 0.82 & 0.56 \\
60 & 1.05 & 0.83 & 0.70 & 0.62 & 0.44 \\
70 & 0.68 & 0.54 & 0.46 & 0.41 & 0.33 \\
80 & 0.37 & 0.28 & 0.25 & 0.23 & 0.21 \\
90 & 0.15 & 0.12 & 0.11 & 0.11 & 0.10 \\
95 & 0.08 & 0.07 & 0.07 & 0.07 & 0.06 \\
\hline
\end{tabular}

TABLE 2 - Per cent of one-minute rale for various periods (in minutes)

\begin{tabular}{c|c|c|c|c}
\hline \multirow{2}{*}{$\begin{array}{c}\text { Cumu- } \\
\text { lative } \\
\text { per } \\
\text { cent }\end{array}$} & \multicolumn{4}{|c}{ Per cent of one minute rate for } \\
\cline { 2 - 5 } & 5 & 10 & 15 & 30 \\
\hline Max. & 54 & 41 & 30 & 18 \\
5 & 77 & 61 & 49 & 30 \\
10 & 80 & 67 & 56 & 34 \\
20 & 79 & 66 & 59 & 35 \\
30 & 82 & 71 & 58 & 36 \\
40 & 80 & 71 & 56 & 36 \\
50 & 80 & 67 & 57 & 39 \\
60 & 79 & 67 & 59 & 42 \\
70 & 79 & 68 & 60 & 48 \\
80 & 76 & 68 & 62 & 57 \\
90 & 80 & 73 & 73 & 67 \\
95 & 87 & 87 & 87 & 75 \\
\hline
\end{tabular}

gages. Figure 1 shows cumulative frequency curves for the 1953 storms. The graph shows cumulative percentages plotted against rainfall rate in inches per hour, based upon one-minute amounts from all 50 gages. For example, in the storm for July 2, 50 pct of the rainfall occurred at rates exceeding 0.90 inch per hour, while for the storm of June 25, 50 pct of the total rainfall occurred at rates exceeding 3.10 inches per hour.

Examination of the 19 storms indicated that the group should be approximately representative of conditions experienced during the warm season in the Midwest. Consequently, the data were combined to determine the frequency of point rainfall rates under average conditions during a season. Results of this analysis are shown in Table 1. It will be noted that on the average (based on oneminute rates in the 19 -storm sample) 50 pct of the warm season rainfall occurs at rates exceeding 1.45 inches per hour. However, the median rate in individual storms in the 19-storm sample was highly variable, ranging from 0.10 to 3.10 inches per hour.

For comparison purposes, the per cent of total storm rainfall occurring at various rainfall rates

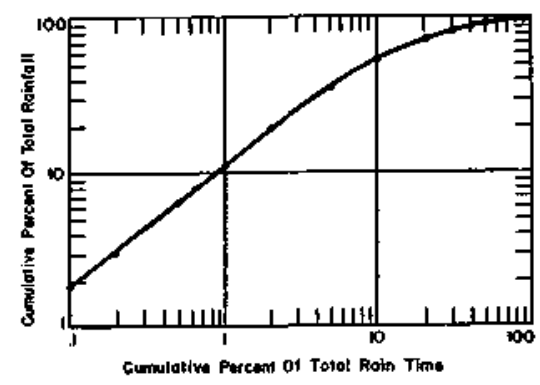

FIG. 2 - Time distribution of point rainfall

TABLE 3 -Frequency of areal rainfall rales

\begin{tabular}{|c|c|c|c|c|c|c|c|c|c|}
\hline \multirow{2}{*}{$\begin{array}{l}\text { Cumu- } \\
\text { lative } \\
\text { per cent } \\
\text { of } \\
\text { rainfall }\end{array}$} & \multicolumn{5}{|c|}{$\begin{array}{l}\text { Rainfall rate (in/hr) equaled or } \\
\text { exceeded for given area (sq. mi) }\end{array}$} & \multicolumn{4}{|c|}{$\begin{array}{l}\text { Per cent of } \\
\text { point rate }\end{array}$} \\
\hline & Point & 10 & 25 & 50 & 100 & 10 & 25 & 50 & 100 \\
\hline ax. & 13.80 & 4.08 & 4.02 & 3.18 & 2.88 & 30 & 29 & 23 & 21 \\
\hline 5 & 5.35 & 3.48 & 2.82 & 2.52 & 2.40 & 65 & 53 & 46 & 45 \\
\hline 10 & 4.20 & 3.18 & 2.55 & 2.22 & 1.86 & 76 & 61 & 53 & 44 \\
\hline 20 & 3.25 & 2.28 & 2.22 & 1.74 & 1.35 & 70 & 68 & 54 & 42 \\
\hline 30 & 2.45 & 1.8 & 1.77 & 1.32 & 1.11 & 73 & 72 & 54 & 45 \\
\hline 40 & 1.90 & 1.26 & 1.26 & 1.02 & 0.90 & 66 & 66 & 54 & 47 \\
\hline 50 & 1.45 & 1.02 & 0.96 & 0.78 & 0.66 & 70 & 66 & 54 & 46 \\
\hline 60 & 1.05 & 0.72 & 0.72 & 0.54 & 0.48 & 69 & 69 & 51 & 46 \\
\hline 70 & 0.68 & 0.48 & 0.48 & 0.36 & 0.28 & 71 & 71 & 53 & 41 \\
\hline 80 & 0.37 & 0.25 & 0.26 & 0.18 & 0.16 & 68 & 70 & 49 & 43 \\
\hline 90 & 0.15 & 0.11 & 0.12 & 0.10 & 0.08 & 73 & 80 & 67 & 53 \\
\hline 95 & 0.08 & 0.07 & 0.07 & 0.05 & 0.04 & 87 & 87 & 62 & 50 \\
\hline
\end{tabular}

TABLE 4 - Time distribution of areal rainfall rates

\begin{tabular}{c|c|c|c|c|c}
\hline \multirow{2}{*}{ Area } & \multicolumn{5}{|c}{$\begin{array}{c}\text { Per cent of total rain time accounting or given } \\
\text { per cent of total rainfall }\end{array}$} \\
\cline { 2 - 6 } & 10 & 25 & 50 & 75 & 90 \\
\hline sq.mi. & & & & & \\
Point & & 3 & 10 & 25 & 48 \\
10 & & 3 & 11 & 26 & 51 \\
25 & & 4 & 11 & 27 & 53 \\
50 & & 4 & 12 & 28 & 55 \\
100 & & 4 & 12 & 30 & 58 \\
\hline
\end{tabular}


was determined when these rates are based on 5-, 10-, 15-, and 30-minute summation periods (Table 2). Obviously, as the time factor is increased in calculating rainfall rates in a storm, the averaging process suppresses details of the high rates occurring during the averaging period. Most studies in the past, such as those of Yarnell [1935] and the U. S. Weather Bureau [1955], on which engineering design has been based have been calculated on the basis of periods from five minutes upward. Hydrologists have found that rainfall rates for periods less than 10 to 15 minutes rarely have practical significance with respect to runoff from a drainage area. However, shorter-period rates, especially one-minute values which closely approximate actual conditions within storms, are pertinent to the understanding of the physical structure of storms. Furthermore, these shortperiod rates have practical application, such as in the evaluation of radar for meteorological purposes, as mentioned previously. In the present study, an attempt was made to ascertain the effect of the averaging process on the observed frequency of rainfall rates.

Referring to Table 1 it is seen that when oneminute totals are used, 50 pct of the rain was found to occur at rates exceeding 1.45 inches per hour. When a five-minute base period was used, the 50 pct value dropped to 1.16 inches per hour and then to 0.97 inch per hour for a ten-minute base period, 0.82 inch per hour for a 15 -minute period and 0.56 inch per hour for a 30-minute period. Also, note in Table 1 the rapid decrease in the maximum observed rainfall rate when this rate is based on various averaging periods. The averaging effect is further illustrated in Table 2, where the longer period values have been expressed as percentages of the one-minute values.

The time distribution of point rainfall was studied next, combining data from all 19 storms. Results of this analysis are shown in Figure 2 where per cent of total rain time has been plotted against per cent of total rainfall. From this curve it is seen that ten per cent of the season rainfall (based on the 19-storm sample) occurs in approximately one per cent of the time it is raining, 50 pct of the rain occurs during about ten per cent of the time that rain is falling, and 90 pct of the total rain occurs in $50 \mathrm{pct}$ of the time that it is raining. Thus, it is apparent that warm season rainfall tends to occur in strong bursts within a storm period; that is, most of the rain tends to occur in a small portion of the storm.

Frequency of areal mean rainfall rates-The foregoing discussion has been concerned with the frequency of point rainfall rates. Frequently, hydrologists and meteorologists are more concerned with areal than with point relationships. Consequently, data for the 19 storms from the 50-gage network on the 100-sq mi watershed were further analyzed to obtain areal frequency relationships. For this purpose, the 100 -sq mi network was further subdivided to give areas of 10, 25, and 50 sq mi for comparison with the 100-sq mi network relationships. One-minute areal mean rates were calculated for each minute in each storm for each of the areas mentioned above.

All 19 storms were then combined to obtain average relationships for the various areas. Reference to Table 3 shows the expected trend. For example, $50 \mathrm{pct}$ of the point rainfall was found to occur at a rate exceeding 1.45 inches per hour, while 50 pct of the areal mean rainfall occurred at rates of 1.02, 0.96, 0.78 and 0.66 inches per hour, respectively, for the 10-, 25-, 50-, and $100 \mathrm{sq} \mathrm{mi}$ areas. Table 4 illustrates the variation in the time distribution of rainfall rates as the area is increased. For example, 50 pct of the point rainfall was found to occur during ten per cent of the time it is raining. At $25 \mathrm{sq} \mathrm{mi}, 50 \mathrm{pct}$ of the areal mean rainfall occurs in $11 \mathrm{pct}$ of the time, while for $100 \mathrm{sq} \mathrm{mi}, 50 \mathrm{pct}$ occurs in 12 pct of the time. This table shows a tendency for the time distribution to change only very slowly with increasing area.

Evaluation of results-Although the results in this study are based upon a relatively small sample, the variety of storms incorporated in the 19-storm sample should make the results approximately representative of the average warm season conditions in the Midwest. It is hoped that the results will prove useful in evaluating the distribution of rainfall rates in warm season rainfall.

\section{REFERENCES}

HUFF, F. A., J. C. NEILL, AND M. SPOCK, Evaluation of low-powered 3-cm radar for quantitative rainfall measurements, Res. Rep. 4, U. S. Army Signal Corps Contract DA-36-039 SC-64723, Ill. State Water Surv. Div., Urbana, pp. 24-34, 1956.

NEILL, J. C, Analysis of 1952 radar and raingage data, Rep. Invest. 21, Ill. State Water Surv. Div., Urbana, pp. 2-6, 1953.

U. S. WEATHER BUREAU, Rainfall intensity-durationfrequency curves, Tech. Paper 25, U. S. Weather Bureau, pp. 1-53, 1955.

YARNELL, D. L., Rainfall intensity-frequency data, U. S. Dept. Agr. Misc. Pub. 204, pp. 1-67, 1935.

\section{Illinois State Water Survey, Urbana, Illinois}

(Manuscript received April 19, 1956, and as revised, June 7, 1956; presented at the Thirty-Seventh Annual Meeting, Washington, D. C, April 30, 1956; open for formal discussion until May 1, 1957.) 